\title{
NAUJAUSIOS TECHNOLOGIJOS IR KOMPIUTERIJOS TERMINIJA
}

\author{
Angelè Kaulakiené \\ Vilniaus Gedimino technikos universitetas, Saulètekio al. 11, LT-10223 Vilnius, \\ el. paštaslkk@vv.vtu.lt
}

Kompiuterijos terminijos 35-eriu metu laikotarpị reikia laikyti pradiniu jos raidos etapu, kuriam büdinga ir sinonimija, ir variantiškumas, kuriuos paprastai lemia tiek ekstralingvistiniai, tiek lingvistiniai veiksniai. Skolinto ar lietuviško termino pasirinkties dalykus dažnai lemia skolinto ir lietuviško termino koreliacijos santykiai. Naujausiu kompiuterijos terminu žodynu Lietuviu kalbos komisijos pirmosios pakopos aprobata rodo, kad minètos srities terminija sisteminama ir norminama, tačiau dar néra visiškai priimtinas lietuviškų ir skolintų terminu santykis, kurį iš dalies lemia specialistu nesutarimas dèl sinoniminiu terminu statuso ir ju pasirinkties.

Reikšminiai žodžiai: kompiuterijos terminija, sinonimija, variantiškumas, kompiuterijos terminų žodynų aprobata.

Prieš kelerius metus viename „Lietuvos ryto“ numerių buvo rašyta, kad naujausi kompiuterijos terminų žodynai (turima omenyje K. V. Paulausko ir R. Jasinevičiaus „Aiškinamasis kompiuterijos žodynas“ (Kaunas: Technologija, 1995. 370 p. - toliau AKŽ) ir V. Dagio, A. Klupšaitès ir A. Žandario parengtas aiškinamasis žodynèlis „Informatika ir kompiuteriu iranga“ (Vilnius: Baltic Amadeus, 1995. 96 p.) kasdienès kompiuterių specialistų ir kompiuterių mėgejuc kalbos nepakeitè. Be abejo, iš karto negalejo pakeisti. Tik praejus šiek tiek laiko galima būtų apie tai kalbèti. Nors iš lyginamosios šių žodynų sinonimijos analizès (Auksoriūtè 1997) matyti, kad palikti ši sudètingą kompiuterijos terminijos kūrimo procesą savieigai negalima.

Dabartiniu metu kiekvienoje kalboje reiškiasi dvilypis procesas: 1) didžiulis naujų terminų antplūdis ir 2) tų naujų terminų (gana didelès dalies) skverbimasis ị bendrinę kalbą, kurios leksikos branduolys ir gramatinè sandara sudaro kalbos esmę, jos nacionalinị savitumą. Dèl tokios intensyvios raidos termininè leksika atei- tyje gali tapti bendrinès kalbos pagrindu, kuris turètų būti ne stichiškai susidariusi termininès leksikos (terminų, terminoidų, kvaziterminų ir pan.) visuma, bet sąmoningai sukurtų terminų, atitinkančių kalbos, logikos, terminologijos reikalavimus, visetas.

Kompiuterijos terminija, palyginti su kitų mokslo sričių terminija, kuriama kiek neịprastai. Pirmosios skaičiavimo tarnybos Lietuvoje buvo pradètos steigti apie 1960 m., o 1969 m. pabaigoje jau veikè nemaža skaičiavimo biurų, skaičiavimo stočių, buvo naudojama gana daug klavišinių ir perforacinių skaičiavimo mašinų.

Kartu su nauja skaičiavimo technika atsirado ir daug naujų įrenginių, ịtaisų, detalių, reiškinių, ypatybių, kurias reikejo pavadinti. Specialistai susidūrè su akivaizdžiu lietuviškų skaičiavimo technikos terminų trūkumu. Šią spragą tuo metu iš dalies užpildè $1971 \mathrm{~m}$. išleistas „Rusų-lietuvių-anglų kalbų skaičiavimo technikos žodynas", kuris ilgą laiką (daugiau nei 20 metų) buvo vienintelis iš tos srities. 
Tik XX a. paskutiniuoju dešimtmečiu buvo padarytas didžiulis šuolis - pasirode keletas didesnių ar mažesnių žodynų. Prie didesnių reikètų priskirti tokius: „Aiškinamasis anglųlietuvių kalbų kompiuterijos terminų žodynas“ (Kaunas: Smaltija, 1997. 366 p.; toliau AKTŽ), lietuvių-anglų-rusų-vokiečių kalbų terminų žodynas „Informatika“ (Vilnius: MII, 1997. 943 p. - toliau I), K. V. Paulausko „Aiškinamasis kompiuterijos terminų santrumpų žodynas“ (Kaunas: Technologija, 2000. 350 p.), V. Žalkausko „Šiuolaikinių kompiuterių programų ir tinklų žodynas" (Vilnius: Mokslo ir enciklopedijų leidybos institutas, 2003. 441 p. - toliau KP) ir pats naujausias „Enciklopedinis kompiuterijos žodynas“ (Vilnius: TEV, 2005. 388 p. - toliau EKŽ), kurio projektas buvo 2003 m. paskelbtas internete ir beveik visus metus svarstomas ir specialistų, ir visuomenès.

Iš mažesnių minètini šie: V. Dagienès, G. Grigo „Mokyklinis aiškinamasis informacinių technologijų žodynèlis“ (Vilnius: TEV, 2003), „Linux“ žodynèlis (Kaunas: Smaltija, 2004), V. Žalkausko „Microsoft Windows“ žodynèlis (Kaunas: Smaltija, 2004) ir „Biuro programų žodynèlis“ (Vilnius: MELI, 2005).

Juose, beje, kaip ir pirmajame žodyne, yra sinonimijos ir šiaip variantiškumo apraiškų, pvz.: aparatine įranga, aparatūra (AKTŽ 104; KP 105), aparatine įranga (plg. techninè įranga, aparatūra) I 121, plg. angl. hardware; braižymo programa, braižykle (EKŽ 40), plg. angl. draw program; derintuve, derinimo programa (EKŽ 52), plg. angl. debugger; failas, rinkmena (AKTŽ 87), rinkmena, failas (EKŽ 252), failas (sin. byla, rinkmena) I 84, plg. angl. file; patrau$k a$, atvirkštinè ìtrauka (pastraipos eilučių patraukimas po pirmaja eilute tam tikru atstumu, pakibusi pastraipos įtrauka) KP 105, plg. angl. hanging; vežimèlis (sin. krietèlè) I 405, plg. angl. carriage; ženkliukas, piktograma (KP 110), plg. angl. icon ir pan.

Tai rodo, kad 35-erių metų kompiuterijos terminijos tarpsnis yra jos kūrimosi etapas, kurio pagrindinès ypatybès - pagrịstoji sinonimija (kai vartojamas tarptautinis ir lietuviškas terminas sąvokai pavadinti) ir variantiškumas (Kaulakienè 2000). Panašiai Lietuvoje rutuliojosi ir kitų mokslo sričių terminija. Tarkime, fizikos terminijos raidos pirmuoju etapu, kuris apèmé 1850-1900 metus, viena sąvoka buvo pavadinta dviem trim, o kartais net keturiais sinonimais (Kaulakienė 1997), pvz.: dujų tamprumas, stamantrumas, stingrumas; lyginamasis, matomasis, reliatyvusis judesys; meridianas, dienovidinis, dienojas; pilas, rezervuaras (bosas), bakas; rezonatorius, atlieptuvas; sziltameris (termometras); termometras, šiltininkas ir pan.

Paanalizavus kitų šalių terminiją, matoma irgi panaši padètis, pavyzdžiui, kroatų kompiuterijos terminijoje (Michaljevic 1998) spausdintuvui, plg. angl. printer vartojama 10 sinonimų ar variantų: printer, štampač, štampalo, ispisivalo, pisač, pisalo, pisaljka, tiskač, tikalo, tiskaljtka; vaizduokliui, plg. angl. display irgi 10 sinonimų: pokazivač, predočnik, ekran predočnik, cijev za podataka, prikazni uredaj, prikazna jedinica, indikatorska naprava, ekran, zaslon, video-jedinica; klaviatūrai, plg. angl. keybord - 5 sinonimai: keybord, kibord, kejbord, tipkovnica, slovište, o meniu, plg. angl. menue, ir sąsajai, plg. angl. interface, -3 sinonimai: meni, jelovnik, izbornik; interfejs, meduskop, sučelje.

Tad galima teigti, kad pradinio lietuviškos kompiuterijos terminijos etapo sinonimija ir variantiškumas yra natūralus jos raidos vyksmas. Tokia dabartinę kompiuterijos terminijos padetí, be abejo, lemia keletas veiksnių.

Pirma, iš dalies kitos kalbos, šiuo atveju anglų kalba. Kaip nurodoma AKŽ pratarmèje, daugelyje mokslo centrų ir laboratorijų vienu metu sukuriama nemaža tų pačiuc ar labai artimų sąvokų, bet dažnai jos pavadinamos skirtingai. Ypač daug kompiuterijos terminų yra anglų kalba, nes šią kalbą vartojančios šalys yra kompiuterių technikos pradininkès. Tokią angliškų sinonimų gausą iš dalies lemia ir tai, kad Anglijoje ir Jungtinèse Amerikos Valstijose nèra valstybinių mokslo ir technikos kalbos norminimo institucijų.

Kita vertus, dabartiniu metu plūstelèjus gausiam naujų kompiuterijos sąvokų srautui, 
dèl kurių dažnai Lietuvoje net patys specialistai nesutaria, iškyla kita problema, būtent: kurị terminą pasirinkti - skolinị ar lietuvišką atitikmeni. Kas lemia, kad įsitvirtina vienas, o ne kitas terminas. Yra keletas veiksnių. Pirmasis - pagrịstosios terminų sinonimijos (lietuviško ir tarptautinio termino) koreliacijos santykiai. Todèl dažnai specialistai nesutaria dèl sinoniminių terminų statuso. Vieni juos laiko sinonimais, o kiti - visai skirtingos reikšmės terminais. Kitas dalykas, susijęs su pagrịstosios sinonimijos koreliacijos santykių nustatymu, tai specialistų nenoras susitarti, ką ir kaip reikia lietuvinti, kuriam iš sinoniminių terminų (skoliniui ar lietuviškam atitikmeniui) teikti pirmenybę ar siūlyti tik vieną iš jų. Dažnai tokio nesutarimo rezultatas ir yra sinoniminių ir iš dalies variantinių terminų pateikties įvairavimas arba nemotyvuotas skolinio (dažniausiai anglybès) pasirinkimas norint jai suteikti tarptautinès leksemos statusą.

Kalbos atžvilgiu, be abejo, ne visada pavyksta nustatyti, kuris terminas (savas ar skolintas) geriau atlieka terminologijos funkcijas. Tokiu atveju kreipiamas demesys i savos kalbos darybos priemonių galimybes, kad galima būtų igyvendinti termino reproduktyvumo (t. y. kad iš jo galima būtų sudaryti kiek įmanoma daugiau darinių) ir vienarūšiškumo (paprastai naujas terminas darybos atžvilgiu turi būti vienarūšis su tos pačios mokslo srities terminais) principus.

Tačiau dažnai šito nepaisoma ir nueinama lengviausiu keliu - daug nesvarstant terminai pasiskolinami iš kitų kalbų. Nors laikantis mūsų pusantro šimto metų turinčios tradicijos turètų būti paisoma grynumo principo. Kalbos grynumo principas nereiškia, kad dabar reikia atsisakyti visų vartojamų skolinių ar neịsileisti i terminiją naujų. Terminai, kaip ir bendrinès kalbos žodžiai, normintini per variantus ir sinonimus. Bet ką daryti, kai nèra iš ko pasirinkti, kai brukte brukami skoliniai: a p l a u d i n g a s, plg. angl. upload (= nusiuntimas; siunta); a t a čm e $n \mathrm{t}$ a s, plg. angl. attachment (= priedas); č a t a s, plg. angl. chat (= pokalbių svetainè); č i p a s, plg. angl. chip (= lustas); j u s e r i s, plg. angl. user (= vartotojas); k e š a s, plg. angl. cache (= priešatmintinè; podèlis); $\mathrm{l}$ i s $\mathrm{t}$ i n g a s, plg. angl. listing (= itraukimas i sąrašą); $\mathrm{m}$ a r š r u t i z a vi m a s, plg. rus. маршрутизация (= maršruto parinkimas); $\mathrm{r}$ o u $\mathrm{m}$ i n g a s, plg. angl. roaming (= tarptinklinis ryšys); s k e n a v i m a s, plg. angl. scan(ning) (= nuskaitymas; žvalga); t i u n e r i s, plg. angl. tuner (= derintuvas) ir pan.

Todèl ypač svarbu su nauja sąvoka atejjusiam kitakalbiam terminui parinkti gerai apgalvotą ir labiausiai tinkantị savos kalbos atitikmenị ir laikytis terminų pastovumo principo. Tačiau tai ne visuomet pavyksta.

Dabartiniu metu tiek kompiuterijos, tiek kitų mokslo sričių specialistų parengti terminų žodynai pateikiami aprobuoti Valstybinei lietuvių kalbos komisijai, kuri yra patvirtinusi terminų žodynų aprobavimo taisykles 59 nutarimu „Dèl terminų žodynų aprobavimo“ (Žin., 1997, Nr. 12-257), kuris yra šiek tiek pakeistas ir papildytas (Gimtoji kalba 2004). Terminų žodynų vertinimo taisyklèse numatyta dvipakopè terminų žodynų aprobata. Pirmoji pakopa: jei terminai pateikiami patenkinamai susisteminti ir sunorminti, poantraštiniame lape įrašoma: „Valstybiné lietuvių kalbos komisija neprieštarauja“. Antroji pakopa tokia. Jei terminai labai gerai susisteminti ir sunorminti, daugumos terminu vertè patikrinta ilgesnès vartosenos, priimtinas lietuviškų ir skolintu terminu santykis, tai žodyno poantraštiniame lape įrašoma: „Valstybinè lietuvių kalbos komisija pritaria“. Visų išleistų kompiuterijos terminų žodynų aprobata yra tik pirmosios pakopos. Tai rodo, kad kompiuterijos terminija yra sisteminama ir norminama, tačiau dar nèra visiškai priimtinas lietuviškų ir skolintų terminų santykis, kurị iš dalies lemia, kaip jau buvo minèta, specialistu nesutarimas dèl sinoniminių terminų statuso ir dažnai nenoras susitarti, ką ir kaip reikètų lietuvinti. Todèl ir turime tokią dabartinę kompiuterijos terminijos padèti. Kokia galètų būti perspektyva? Pirmiausia, be abejo, kompiuterijos, kaip ir kitų mokslo sričių, perspektyva 
priklausys apskritai nuo valstybinès kalbos politikos dalykų. Kiek dabar žinoma iš spaudos ir ìvairių diskusijų lietuvių mokslo kalbos ateitis yra labai neaiški. Primygtinis siūlymas, kuris gali tapti ir îstatymu, rašyti mokslo straipsnius anglų kalba kelia labai didelị pavojų lietuvių mokslo kalbai ir jos terminijai.

\section{Literatūra}

Auksoriūtè, A. 1997. „Kai kurie sinonimijos atvejai naujausiuose kompiuterijos terminų žodynuose“, iš Terminologija ir dabartis. Mokslo darbai. Kaunas:

Technologija, 15-19.
Kaulakienè, A. 1997. „Fizikos terminijos raidos tarpsniai“, Lituanistica 3(31): 66-73.

Kaulakienė, A. 2000. „Kompiuterijos terminijos sinonimija: yda ar būtinybë", Terminologija 6: 23-28.

Michaljevic, M. 1998. "Recent Developments in Croatian Computer Terminology", iš Towards a European Terminology. Internacional Conference. Budapest, 31-32.

Nutarimas dèl terminų žodynų vertinimo taisyklių patvirtinimo (2004 m. birželio 3 d. Nr. 8(97), Gimtoji kalba 2004, 6: 28-30.

\title{
TERMINOLOGY OF THE NEWEST TECHNOLOGIES AND COMPUTERING
}

\author{
Angelè Kaulakienè
}

The thirty-five-year period of computer terminology has to be considered the initial stage of its evolution where synonymy and variability are characteristic features, which are usually determined by both extralinguistic and linguistic factors. The choice of borrowed or Lithuanian terms is often determined by the relationship between borrowed and Lithuanian terms. The first stage of the newest dictionaries of computer terms approbated by the Commission of the Lithuanian Language shows that the terminology of the mentioned field is being systematized and normalized. However, the ratio between Lithuanian and borrowed terms is not fully acceptable yet, and it is partially determined by disagreement among specialists on the status of synonymous terms and the choice of them.

Keywords: computer terminology, synonymy, variability, approbation of the dictionaries of computer terminology.

Iteikta 2006-04-20; priimta 2006-05-16 